\title{
Effort to increase rubber farmers' income when rubber low prices
}

\author{
Iman Satra Nugraha*; Aprizal Alamsyah; Sahuri \\ Sembawa Research Center, Indonesian Rubber Research Institute, Palembang \\ *To whom correspondence should be addressed.Email:iman_satra@yahoo.com
}

\begin{abstract}
Rubber is a plantation crop that has high economic value and the largest foreign exchange producer 10. Rubber producers in Indonesia consist of the islands of Sumatra and Kalimantan. Indonesia is one of the largest rubber producers after Thailand with the number of people involved in rubber farming reaching 2.2 million households. The recent decline in rubber prices has affected the decline in rubber farmers' income. So a strategy is needed to increase the income of rubber farmers. This paper provides an overview of the strategies that rubber farmers need to increase their income. The strategy that was carried out was an increase in the adoption of superior clones at the farmer level, optimization of rubber plantations by modifying the distance of rubber plants to be wider so that they could be used to plant intercrops during the rubber crop cycle and farmers using rubber marketing through UPPB (row rubber material processing and marketing unit)because it could increase the share price received by farmers so farmers get high prices.
\end{abstract}

Keyword : farmers' income, rubber price, strategy

JEL Classification: Q1, Q11,Q13

\section{INTRODUCTION}

Indonesia is the second largest rubber producing country in the world after Thailand, based on statistics from the Indonesian Directorate General of Agriculture (2015) and the Coordinating Ministry for Economic Affairs (2011). is one of the export commodities that contributes to the country's foreign exchange from the non-oil and gas sector and important commodities to improve the welfare of rubber farmers. This can be seen from the level of control of smallholder rubber by $85 \%$, the rest is controlled by rubber private state and the government state. So that if a decline in rubber prices will affect the income of rubber farmers. The price of rubber in recent years has experienced sharp fluctuations.

The following are the rubber price fluctuations presented in Figure 1.In Figure 1 shows that rubber prices fluctuate every year. In 2009 it decreased to below 2 USD per $\mathrm{kg}$ and the peak of rubber prices occurred in 2011 reaching USD 4 per $\mathrm{kg}$. But in recent years the price of rubber has decreased sharply, which only reached USD 1.4-1.5 per kg. This condition resulted in unstable rubber farmers' income. According to Syarifah et al. (2015), Regina (2016), and Hardiwan (2018) the negative impact of falling rubber prices for farmers is: 1) Many farmers stop their rubber farming activities and change professions; 2) Many rubber lands are converted to other commodities; 3) People's purchasing power is weak; 4) The level of community welfare decreases; 5) Many vehicle loans are stuck; 6) Crime increases; and 7) Quality of health and education is 
low. Based on these problems the author will review what effort should be done by smallholder rubber farmers to overcome low rubber prices so that farmers' income can be stable and can meet family needs. with these efforts, farmers are expected to be able to maintain stable income and even increase.

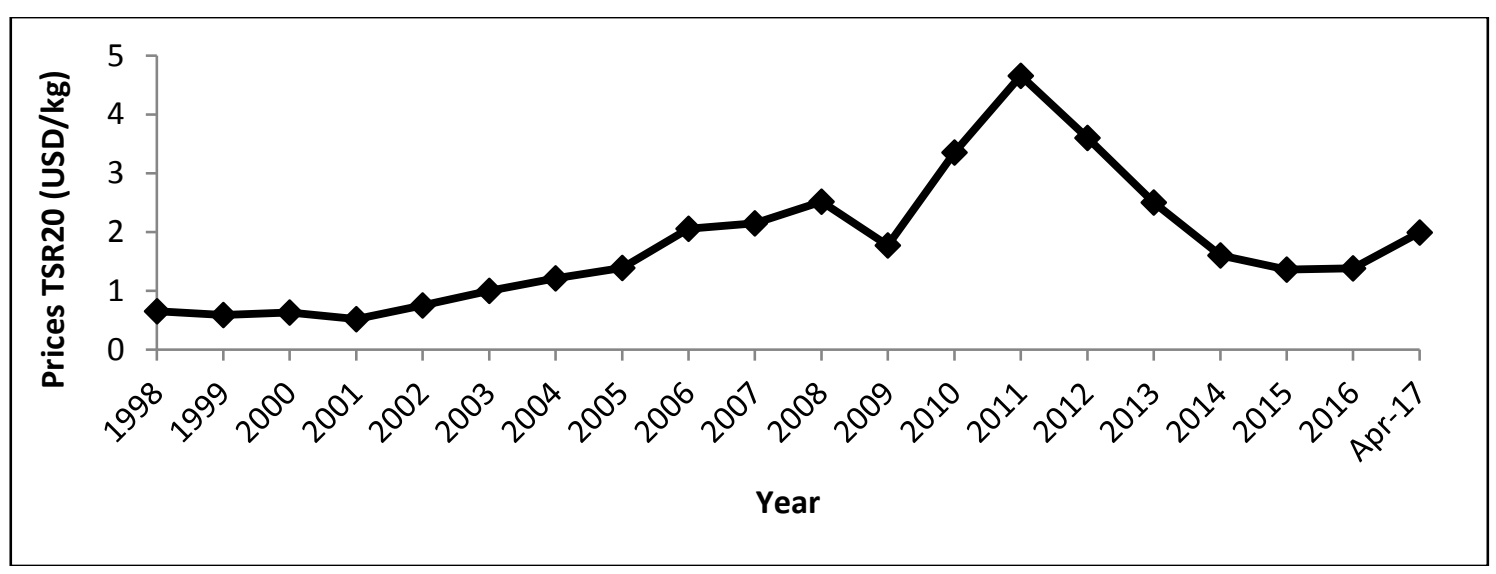

Figure 1. Rubber price fluctuations in 1998 - 2017

Source : Sicom, 2017

\section{METHODS}

This research includes the type of literature study by looking for references to theories that are relevant to cases or problems found. Theoretical references obtained by means of literature study are used as the basic foundation and the main tools for research practice in the field.The type of data used by the author in this study is primary data by conducting observations and secondary data, namely data obtained from journals, documentation books, and the internet. Documentation is a method for finding documents or data that are considered important through newspaper / magazine articles, journals, libraries, brochures, documentation books and through electronic media, namely the internet, which has to do with the application of this research.

Literature study is a method used to collect data or sources related to the topic raised in a study. Literature studies can be obtained from various sources, journals, documentation books, internet and libraries. The data that has been obtained is then analyzed by descriptive analysis method. Descriptive analysis method is done by describing the facts which are then followed by analysis, not merely outlining, but also providing sufficient understanding and explanation.

\section{RESULTS AND DISCUSSION}

Rubber is a strategic commodity because these commodities can increase the country's foreign exchange, open jobs and increase family income. The price of rubber at the time was relatively low, which affected the income of rubber farmers. Rubber prices occur based on market mechanisms so they cannot be changed. However, there are some efforts made by farmers so that they can increase the income of rubber farmers such as increased crop productivity, increased land productivity and Marketing of Row Rubber Material.

\section{Increased crop productivity}

Rubber is one of the important plantation commodities, both as a source of income, employment opportunities and foreign exchange, a driver of economic growth 
in new centers in the area around rubber plantations and the preservation of the environment and biological resources. But as the country with the largest area and the second largest production in the world, Indonesia still faces several obstacles, namely low productivity. The low productivity of rubber in plantations is generally caused by the lack of optimal management of the use of recommended clones. Therefore, to optimize the productivity of rubber plants can be achieved by selecting high-producing clones (Boerhendhy and Amypalupy, 2010; Marimin, et. al, 2013).

Indonesia's rubber productivity occupies the lowest level among rubber producing countries such as Thailand and Malaysia. The productivity of folk rubber in Indonesia is $800-900 \mathrm{~kg} / \mathrm{ha}$ while for new private estate it reaches $1,000-1,200 \mathrm{~kg} / \mathrm{ha}$ (Ditjenbun, 2007; Indonesia Investment, 2018). According to Suharto (2013) and Riadi et al. (2011) one reason for the small productivity of Indonesian rubber is that more than $40 \%$ of smallholder rubber plantations still use seedling material and do not thoroughly adopt the recommended technology in implementing rubber cultivation. As an illustration, the use of Malaysian clonal plants is $90 \%$, Thailand is $95 \%$, India is $99 \%$, and Vietnam is $100 \%$ (Ditjenbun 2008). Therefore, the productivity of other rubber producing countries has reached 1,500-1,700 kg/ ha kk. So that one strategy to increase the growth of the plantation sub-sector can be done by replanting with clonal seedlings and expanding farming (Kirana Megantara, 2017; Budi, 2014). Old and damaged rubber farm also contributed to the decline in rubber plantation productivity because production per tree followed by a low population per hectare resulted in garden productivity being so low that it was not economical. Therefore, the replanting time needs to be based on the calculation of the amount of production and economic value. Low productivity farm (400-500 kg / ha / year) with dry rubber prices of Rp. 7,000 / kg are recommended to be replanting because they are not economical (Karyudi et al. 2001).

Increasing productivity of plants using superior seeds is very different from seedling because superior clone seeds have high productivity potential, reaching 1,5002,500 kg / ha (Aidi-Daslin, 2005 and Nurhawaty and THS, 2013). However, to increase crop productivity is not separated from the correct guidelines for making the right seeds, starting from rootstock selection, selection of entres, and application of cultivation techniques which include tillage, fertilization with dosage, frequency, and proper application method, and control of fungal diseases white root, application of exploitation systems according to the physiological properties of clones and control of tapping grooves. If all that has been done, it will get high plant productivity. Increased productivity is important because with the higher productivity of plants, the yield received by farmers in quantity will also increase compared to the use of natural seeds (seedling).Rubber producer productivity can be seen in Table 1.

Table 1. Rubber producer productivity

\begin{tabular}{clc}
\hline No & Country & Produktivity (kg/ha/yr) \\
\hline 1 & Indonesian & 1.045 \\
2 & Thailand & 1.700 \\
3 & Malaysia & 1.500 \\
4 & India & 1.400 \\
5 & Sri Lanka & 809 \\
\hline
\end{tabular}

Source : Primary, 2018

\section{Increased land productivity}

The condition of low rubber prices is a problem for farmers because it will reduce the income level of farmers. To increase farmers' income, innovation is needed to 
optimize land productivity. One way to increase land productivity is by using rubber plantations to plant intercrops between rubber. Planting intercrops among rubber plants can increase farmers' income, soil organic matter increases, soil fertility increases both physically and chemically, and rubber plant growth increases (Rodrigo et al. 2004; Raintree 2005; Pathiratna \& Perera 2005; Pathiratna 2006; Rosyid 2007 ; Ogwuche et al. 2012; Xianhai et al. 2012; 2015 Panic; Sahuri \& Rosyid 2015). Financially, intercropping can also provide additional income for farmers. Corn farming as a rubber intercropping plant at a low price is still profitable with an $\mathrm{R} / \mathrm{C}$ ratio of 1.62 , whereas at a high price it is very profitable with an $\mathrm{R} / \mathrm{C}$ ratio of 2.27 (Sahuri, 2017). So economically, intercrop farming benefits farmers even though the income will be lower than if the intercrops are planted in monoculture.

This low income is caused if intercropping, the land area used for intercropping cannot be done entirely for intercropping, and also every year the production will decrease along with the reduction in light intensity. For the spacing that was previously recommended is $6 \mathrm{~m} \times 3 \mathrm{~m}$, with the planting distance rubber farmers can only optimally utilize interlocutors between rubber for 0-3 years, this is not yet the limiting factor during that period (Saptabina, 2012). After more than 3 years the sunlight will be a limiting factor because the canopy of rubber plants has covered the sunlight so that the plants among the rubber do not get enough sunlight for photosynthesis.

Innovations that can be developed so that intercrops between rubber can run throughout the year using a wide spacing pattern. This innovation has been implemented in several provinces in Indonesia such as in South Sumatra, West Kalimantan, Jambi and others. Size of spacing used for wide spacing ranging from $18 \mathrm{~m}$ - 20m (Sahuri, 2017). With the spacing, it can utilize the gaps between rubber by planting interlaced plants for a long time. In addition to increasing farmers' income, these innovations can also support government programs to accelerate food security (Hartati, 2015).

\section{Marketing of row rubber material}

Row rubber materal marketing is the end result of rubber cultivation activities that have been tapped by farmers. Rubber farmers conduct tapping to remove the sap that is inside the rubber tree by injuring the latex vessels found on the skin of rubber plants. Tapping is done every day by farmers. The reason for farmers tapping rubber every day is to get a lot of sap so that it can generate family income. Farmers sell sap products once a week. The decline in the selling price of rubber greatly affected the income and welfare of farmers. Based on the research of Hafsah et al. (2014) and Kurniawan et al. (2012) stated that $36.84 \%$ of farm income is lost and $66.67 \%$ of plasma rubber farmers' welfare decreases due to a decrease in rubber selling prices.

Rubber prices cannot be interrupted because they are formed by the mechanism of the world market so that if world rubber prices fall then domestic rubber prices will follow suit. But there are several ways that farmers can do to increase the portion of prices received by farmers so that the price received by farmers is also high. In general, rubber farmers still use traditional marketing, namely selling bokar to village traders, collecting traders and so on. The marketing chain makes the marketing chain inefficient and the bargaining position of farmers is weak because it is still dependent on intermediary traders (Lismarwati, 2016). The impacts of traditional marketing are as follows an intermediary trader will master the price of rubber, the absence of price transparency at the farmer level, the portion of prices received by farmers is low, and the quality of rubber is not in accordance with SNI. 
On the other hand farmers still need middlemen for various reasons such as being bound emotionally (tied to loans) to traders, farmers still not paying attention to the quality of row rubber material bokar by using freezers not recommended and mixing tatal into row rubber material bokar so that bokar is heavier (Vachlepi et al. 2016). Without realizing it by farmers, all activities carried out by farmers will have an impact on the quality of the final bokar produced which will be low and the price received by farmers is also low.

Activities that can be done by farmers to increase the share of prices through organized marketing. One type of organized marketing is the Row Rubber Material Processing and Marketing Unit (UPPB). The existence of UPPB can be an intermediary to guide rubber farmers to always produce clean and good quality row rubber material bokar. Row rubber material bokar processing and marketing unit is a business unit formed by two or more planters groups to carry out technical guidance, processing and marketing activities for bokar. UPPB has legality with the existence of STR-UPPB, namely a registration certificate registered in the regency / city government. UPPB is one of the right choices for rubber farmer groups because it increases the bargaining position of farmers and farmer prices and can improve the quality of row rubber material bokar (Alamsyah, et al. 2017).

This marketing has rules of the game so that with these rules can improve the quality of bokar, the rules of the game are frozen latex using ant acids, free of contaminants, not soaked, selling bokar with the same age. The marketing chain of UPPB is also relatively short, ie farmers or farmer groups or Gapoktan collectively collect the sap in a location and then it will be auctioned to buyers from the factory, the buyer bidding the highest price will get the sap. With this system the marketing chain is very effective and efficient because the portion of the price received by farmers becomes large and farmers no longer think of shrinkage costs, transportation if they directly sell to the factory. The price difference received by farmers between using marketing through UPPB and traditional amounts to Rp. 2,000-Rp. 3,000 per $\mathrm{kg}$ (Junaidi, 2017). At present the UPPB (South Sumatra Province) has contributed 63,000 tons per year from the total of 169 UPPB to crumb rubber factories as factory raw materials (Anung, 2018).

\section{Government policy on rubber commodities}

Smallholder rubber farmers involved in rubber farming reach 2.2 million households (Junaidi, 2017). Therefore rubber farmers need to be supported to increase the income of their families to become more prosperous families. Indonesian rubber farmers still use a lot of seedling seeds so that the productivity of their crops is very low. In conditions of low rubber prices and accompanied by low crop productivity it will greatly affect farmers' income. Therefore a policy is needed to rejuvenate rubber using superior clones that have potential above $1,500 \mathrm{~kg} / \mathrm{ha}$. The policy will increase the adoption of superior clones of Indonesian rubber farmers, which are still below other rubber producing countries. On the other hand, the government can also recommend rubber farmers to optimize rubber plantations that have not yet been produced and can modify the spacing of rubber into a wide spacing. With this wide spacing, farmers can optimize rubber plantations to grow crops other than rubber such as seasonal crops so that farmers get income other than rubber plants. The use of annual crops can be carried out throughout the year because the distance between rubber plants reaches $18 \mathrm{~m}-20 \mathrm{~m}$, so that light between rubber when producing rubber plants is still available for annual crops. However, this policy should be accompanied by the 
provision of marketing so that farmers do not worry about the marketing of the products they harvest.

The Clean Bokar National Movement program through the UPPB, which is set forth in the form of regulations and provisions, must still be supported by the duties and responsibilities of the local government whose administrative area is the center of people's plantations. Regional governments are required to play a role in developing and supervising activities related to processing and marketing of bokar in their regions. Regional regulations are intended to provide guidelines for the management of natural rubber in their respective regions from the upstream to downstream sectors. Regional regulations which become guidelines in monitoring the continuity of bokar processing activities. So that farmers / farmer groups / farmer groups will feel more attention and the price portion received by farmers is always higher than traditional marketing. In addition, it also gives sanctions to each actor (farmer, trader and factory) if playing is not in accordance with the applicable rules. This sanction will give a deterrent effect to these business actors so as to create a sustainable and growing UPPB.

\section{CONCLUSIONS AND RECOMMENDATIONS}

\section{Conclusions}

The decline in rubber prices is a problem for farmers that must be faced by rubber farmers. The low price of rubber has resulted in a decrease in the income of rubber farmers. The strategy that can be applied by farmers to deal with low rubber prices is to increase the adoption of superior seeds when replanting old rubber, optimizing rubber plantations by modifying wide spacing so that they can plant intercropping throughout the year and increasing farmers' awareness of conducting organized marketing through UPPB so that the the price received by farmers will be higher.

\section{Recommendations}

Government provides support to smallholder rubber plantations in the form of increased adoption of superior clones through a rubber plantation replanting program, oversee Minister of Agriculture Regulation No. 38/2008 concerning clean row rubber material, and make regulations and support marketing of rubber so that the price of rubber can be uniform both in terms of price, quality and time of sale.

\section{REFERENCES}

Aidi-Daslin. (2005). Kemajuan pemuliaan dan seleksi dalam menghasilkan kultivar karet unggul. hlm. 26-37. Prosiding Lokakarya Nasional Pemuliaan Tanaman Karet, Medan, 22-23 November 2005. Balai Penelitian Sungei Putih, Pusat Penelitian Karet, Medan

Alamsyah. A., Nugraha. I.S., Agustina. D.S., dan Vachlepi.A. (2017). Tinjauan Penerapan Unit Pengolahan Dan Pemasaran Bokar Untuk Mendukung Gerakan Bokar Bersih Di Sumatera Selatan. Warta Perkaretan. 36(2) :159-172.

Anung. (2018). Pertemuan Koordinasi Teknis Pengolahan Bokar Bersih. Paparan Materi pada tanggal 24-27 September 2018. Palembang. Sumatera Selatan.

Boerhendhy. I., dan Amypalupy. K. (2010). Optimalisasi Produktivitas Karet Melalui Penggunaan Bahan Tanam, Pemeliharaan, Sistem Eksploitasi, Dan Peremajaan Tanaman. Jurnal Litbang Pertanian. 30(1):23-30.

Budi. Y.P. (2014). Strategi Peningkatan Produktivitas Karet Di PT. Perkebunan Nusantara XII (Persero) Kebun Kendenglembu Kabupaten Banyuwangi 
(Skripsi). Fakultas Pertanian. Universitas Pembangunan Nasional Veteran Jawa Timur. Surabaya. Indonesia.

Ditjenbun. (2015). Statistik Perkebunan Indonesia Karet 2014-2016. Direktorat Jenderal Perkebunan. Jakarta. Indonesia.

Ditjenbun. (2007). Statistik Perkebunan Indonesia: Karet. Direktorat Jenderal Perkebunan, Jakarta.

Ditjenbun. (2008). Sambutan Direktur Jenderal Perkebunan (Ditjenbun) pada Lokakarya Nasional Agribisnis Karet, Yogyakarta. 20-21 Agustus 2008.

Hafsah. F. M., Violetta. P. S., dan Pratama. C. (2014). Analisis Pendapatan Dan Tingkat Kesejahteraan Petani Karet Perkebunan Plasma Desa Sungai Hijau Kecamatan Pangkalan Banteng Kabupaten Kotawaringin Barat Kalimantan Tengah (Laporan Akhir). PKM - Penelitian. Institut Pertanian Bogor. Indonesia.

Hardiwan. D. (2018). Harga Karet Rendah, Begini Dampak Secara Tidak Langsung ke Investasi. http://jambi.tribunnews.com/2018/05/16/harga-karet-rendah-beginidampak-secara-tidak-langsung-ke-investasi (5 Oktober 2018).

Hartati. S. (2015). Perubahan Jarak Tanam Karet dan Pola Integrasi Mendukung Ketahanan Pangan Kalimantan Selatan. http://kalsel.litbang.pertanian.go.id/ind/index.php?option=com_content\&view=a rticle\&id=506:karet\&catid=15:benih\&Itemid=43 diakses pada 10 Oktober 2018 .

Indonesia Invesment. (2018). Karet Alam. https://www.indonesiainvestments.com/id/bisnis/komoditas/karet/item185? (7 Oktober 2018).

Junaidi. D. (2017). Evaluasi Pelaksaan Bokar Bersih. Paparan Materi dari Kementerian Pertanian 24 Oktober 2017. Banjarbaru.

Karyudi., Azwar., Sumarmadji., Istianto. I. Suhendry, M. Supriadi, C. Nancy, Sugiharto, Sudiharto, dan U. Junaidi. (2001). Analisis biaya produksi dan strategi peningkatan daya saing perkebunan karet nasional. Warta Pusat Penelitian Karet 20(1-3): 1-24.

Kementerian Koordinator Bidang Perekonomian. (2011). Masterplan Percepatan dan Perluasan Pembangunan Ekonomi Indonesia 2011-2025. Kementerian Koordinator Bidang Perekonomian, Jakarta.

Kirana Megantara. 2017. Program Peremajaan dan Peningkatan Produktivitas Karet Petani. https://www.kiranamegatara.com/blog/get/program-peremajaan-danpeningkatan-produktivitas-karet-petani (6 Oktober 2018).

Kurniawan, A., Nuraini., dan Khosmas. (2012). Analisis Pendapatan Petani Karet Lateks di Desa Pangkalan Baru Kecamatan Tempunak Kabupaten Sintang (Skripsi). Program Studi Pendidikan Ekonomi. FKIP Untan Pontianak. Indonesia.

Lismarwati. (2016). Analisis Pemasaran Karet Rakyat di Kabupaten Sijunjung (Tesis). Ilmu Ekonomi Pertanian. Universitas Andalas. Indonesia.

Marimin., Muhammad. A.D., Machfud., Muhammad. P.I.F.P. (2013). Peningkatan Produktivitas Proses Budidaya Karet Alam Dengan Pendekatan Green Productivity: Studi Kasus Di Pt. Xyz. Agritech. 33(4) : 433-441.

Nurhawaty dan THS. (2013). Evaluasi Produktivitas Tanaman Karet Dengan Sistem Tanam Ganda Pada Skala Komersial. Warta Perkaretan. 32(1): 16-24.

Ogwuche. P., Umar. H.Y., Esekhade. T.U., Francis. S.Y. (2012). Economies of intercropping natural rubber with arable crops: a panacea for poverty alleviation of rubber farmers. Journal of Agriculture and Social Sciences. 8(3): 100-102. 
Pathiratna. L.S.S. (2006). Management of intercrops under rubber: implications of Competition and possibilities for improvement. Bulletin of the Rubber Research Institute of Sri Lanka. 47: 8-16.

Pathiratna. L.S.S., Perera. M.K.P. (2005). Effect of competition from rubber (Hevea) on the yield of intercropped medicinal plants, Solatium virginianum Schrad., Aerva lanata (L.) Juss. Ex. Schult and Indigofera tinctoria L. Journal of the Rubber Research Institute of Sri Lanka. 87: 36-45.

Pansak W. (2015). Assessing Rubber Intercropping Strategies in Northern Thailand Using the Water, Nutrient, Light Capture in Agroforestry Systems Model. Kasetsart Journal. 49: 785-794.

Raintree J. (2005). Intercropping with Rubber for Risk Management. In: Improving Livelihoods in the Upland of the Lao PDR: Options and Opportunities. National Agriculture and Forestry Research Institute (NAFRI), National Agriculture and Forestry Extension Service (NAFES), and National University of Lao PDR (NUOL). 2: $41-46$.

Regina Y. (2016). Dampak sosial pasca penulisan harga karet (Studi di Desa Mangat Baru Kecamatan Dedai Kabupaten Sintang, Kalimantan Barat). Jurnal Sosiologi. 4(2): 1-17.

Riadi, F., Machfud, Tajuddin, B. dan Illah, S. (2011). Model pengembangan agroindustri karet alam terintegrasi. Jurnal Teknologi Industri Pertanian. 21(1): 146-153.

Rodrigo VHL, Silva TUK, Munasinghe ES. (2004). Improving the spatial arrangement of planting rubber (Hevea brasiliensis Muell. Arg.) for longterm intercropping. Field Crops Research. 89(2-3): 327-335. http://doi.org/d87mwf.

Rosyid MJ. (2007). Pengaruh Tanaman Sela terhadap Pertumbuhan Karet pada Areal Peremajaan Partisipatif di Kabupaten Sarolangun, Jambi. Jurnal Penelitian Karet. 25(2): 25-36.

Sahuri, Rosyid MJ. (2015). Analisis usaha tani dan optimalisasi pemanfaatan gawangan karet menggunakan cabai rawit sebagai tanaman sela. Warta Perkareta. 34(2): 77-88. http://doi.org/b6dx.

Sahuri. (2017). Pengaturan Pola Tanam Karet (Hevea brasiliensis Muell.Arg.) untuk Tumpang Sari Jangka Panjang. Jurnal Ilmu Pertanian Indonesia (JIPI). 22 (1): 46-51. DOI: 10.18343/jipi.22.1.46

Sahuri. (2017). Pengembangan Tanaman Jagung (Zea Mays L.) Di Antara Tanaman Karet Belum Menghasilkan. Analisis Kebijakan Pertanian. 15(2) : 113-126. DOI : http://dx.doi.org/10.21082/akp.v15n2.2017.113-126

Saptabina Usahatani Karet Rakyat. (2012). Pola Tanaman Sela. Balai Penelitian Sembawa. Sumatera Selatan. pp 47.

Suharto. (2013). Produktivitas karet harus ditingkatkan. http://id.beritasatu.com/agribusiness/produktivitas-karet-petani-harusditingkatkan/72782 (05 Oktober 2018).

Syarifah FL, Agustina DS, Nancy C, Supriadi M. (2015). Socio-economic condition as affected by fall of natural rubber price: case study in South Sumatra. International Rubber Conference, Ho Chi Minh, Vietnam, November 2-3.

Vachlepi. A., Nugraha. I.S., dan Alamsyah.A. (2016). Mutu Bokar dari Kebun Petani di Areal Operasional Tambang Kabupaten Musi Banyuasin. Jurnal Standardisasi. $18(2) ; 83-90$.

Xianhai Z, Mingdao C, Weifu L. 2012. Improving planting pattern for intercropping in the whole production span of rubber tree. African Journal of Biotechnology. 11(34): 8484-8490. http://doi.org/b54h 